\title{
Editor, Executive and Entrepreneur
}

\author{
Strategic Paradoxes in the Digital Age
}

\author{
Tor-Bøe Lillegraven \& Erik Wilberg
}

\begin{abstract}
To survive in today's increasingly complex business environments, firms must embrace strategic paradoxes: contradictory yet interrelated objectives that persist over time. This can be one of toughest of all leadership challenges, as managers must accept inconsistency and contradictions. In this article, we develop and empirically test a set of hypotheses related to ambidexterity, a key example of a paradoxical strategy. Through our analysis of data from a survey of executive leaders, we find a link between organizational ambidexterity and strategic planning, suggesting that the complexities of navigating in explorative ventures require more explicit strategy work than the old certainties of a legacy business. We identify and discuss inherent paradoxes and their implications for firm performance in 22 industry-specific strategies, where empirical industry data shows a pattern of conflict between explorative growth strategies and exploitative profit strategies. We argue that this is just one of the inherent paradoxes in the ambidexterity construct.
\end{abstract}

Keywords: ambidexterity, leadership, strategy, paradoxes, organizational change

\section{Introduction}

An emerging idea in strategic management studies is that, in the highly competitive business environments of the twenty-first century, being very good at just one thing is not enough. To survive and prosper over time, firms must be ambidextrous - able to implement both incremental and revolutionary change - by continuously exploiting their existing business while simultaneously exploring new and potentially disruptive market opportunities (March, 1991; Tushman \& O'Reilly, 1996). However, exploration and exploitation are associated with conflicting business logics that create fundamental strategic challenges for firms and their leaders (Smith \& Tushman, 2005). Exploitation aims to refine products in existing markets, whereas exploration seeks to introduce new products and services to uncharted markets. Undertaken simultaneously, they create a strategic paradox: "contradictory yet interrelated demands embedded in an organization's goals" (Smith, 2014, p. 1592). Paradoxes denote tensions that coexist and persist over time, pose competing demands that require ongoing adaption and change, and defy resolution (Lewis, 2000). The strategy literature is full of examples of the paradoxes faced by organizations, including tensions between corporate synergies and business unit specialization, between financial viability and social responsibility, and between high growth and high profitability; however, we still know little about the specific nature and 
management of strategic paradoxes (Smith, 2014, p. 1593). Effectively implementing and managing contradictory business objectives is complex and challenging, yet a research gap remains regarding exactly how leaders plan and execute paradoxical strategic intent (O'Reilly \& Tushman, 2013). This paper addresses this gap by examining how executive leaders manage conflicting strategic priorities in response to environmental and internal pressures for change. Does a readiness for change help organizations simultaneously to explore and to exploit, to "become" ambidextrous? Do multiple, conflicting objectives lead to more explicit, written strategic planning, or alternatively to a more laissez-faire approach given the complexities involved?

The empirical setting of this study is the newspaper industry, which provides a particularly relevant context for studying how incumbent firms adapt paradoxical strategies in response to increasingly complex business environments (O’Reilly \& Tushman, 2013; Smith, Binns, \& Tushman, 2010). Over the past decade, newspaper readers and advertisers have been migrating to digital media, leaving the industry in a constant state of change. Smith and Lewis (2011), in their study of strategic paradoxes, noted that such increased environmental dynamism may encourage leaders to push the boundaries of both explorative and exploitative strategies. The strategic tensions become more prominent in "complex settings" where there are overlapping technological paradigms. Such is arguably the case in the newspaper industry, where digital media over the past twenty years have competed for primacy over the legacy printed newspaper. For leaders, this introduces a strategic dilemma: should they focus on what they know well - keeping their current newspaper businesses profitable - or should they attempt to compete with Facebook, Google, Twitter and the like for future digital revenues? The answer is probably that they must do both; an either/or response to these strategic tensions is likely to be inadequate (Smith et al., 2010). In the digital age, leaders may be charged with being editors, executives, and entrepreneurs. As editors, their responsibility is to uphold ethical and journalistic standards across different media platforms. As executives, they must ensure the financial sustainability of their current products while growing new revenue streams. As entrepreneurs, they have to outsmart the Silicon Valley start-ups to build new digital business opportunities that disrupt their existing print businesses. In sum, industry leaders are charged with making choices and trade-offs among competing, conflicting, and often paradoxical strategies (Jansen, Vera, \& Crossan, 2009; March, 1991; Smith et al., 2010; Smith \& Lewis, 2011; Tushman \& O’Reilly, 1996).

Our contribution to the current research on strategic paradoxes and ambidexterity is three-fold. First, our study links a firm's readiness for change with both exploration and exploitation, suggesting such readiness may indeed help firms sustain ambidextrous strategies. Second, we link ambidexterity to strategic planning, suggesting that the complexities of navigating explorative ventures require more strategy work than the old certainties of the legacy business. Finally, we discuss paradoxes involving 22 industry-specific strategic initiatives, giving new insights into the financial viability of ambidexterity strategies. In the following section, we propose a set of hypotheses, grounded in theory, which are to be empirically tested; then, we present our findings; finally, we conclude the paper with a discussion of the theoretical and practical implications of our study. 


\section{Theory and Hypotheses}

One of the cornerstones of modern management theory is the idea that the consistent manipulation of organizational structure and resources is the key to financial success. Strategic management can be framed as a series of processes aimed at regulating the actions of the organization so as to achieve consistent firm performance. However, the need for stability can be self-destructive in the long run. Prone to the success paradox (Tushman \& O'Reilly, 1996), incumbent firms may resist change, ignoring business strategies regarded as disruptive to the current recipe for success and favouring the activities they know best (Benner \& Tushman, 2003; March, 1991). In this view, sometimes called punctuated equilibrium, fundamental change occurs only through an interruption - disruption - of the status quo, either by the direct intervention of executive leadership or by an external event such as a new technological paradigm (Christensen, 1997; Tushman \& Romanelli, 1985). These disruptions (punctuations) can lead to an upheaval in an organization's deep structures, leaving it in disarray until the disturbance ends and new stability is found. From this viewpoint, organizations inevitably gravitate toward a state of equilibrium in which managers fall back on learned patterns of exploitative response, as "the certainty, speed, proximity, and clarity of feedback ties exploitation to its consequences more quickly and more precisely than is the case with exploration" (March, 1991, p. 73). Levinthal and March (1993) called this the myopia of learning: firms tend to rely on strategies that are proximate, less risky, and more measurable. Such resistance to change is rational, but it can also be self-destructive in the long run, as firms and managers risk losing their competitive edge.

Table 1. The Ambidexterity Paradox: Conflicts Between Exploitative and Explorative Strategic Intent

\section{Exploitative activities Exploratory activities}

\begin{tabular}{lll}
\hline $\begin{array}{l}\text { Strategic intent } \\
\text { Critical tasks }\end{array}$ & $\begin{array}{l}\text { Cost control, profit } \\
\text { Operations, efficiency, } \\
\text { incremental innovation }\end{array}$ & $\begin{array}{l}\text { Innovation, growth } \\
\text { Adaptability, new products, } \\
\text { breakthrough innovation }\end{array}$ \\
Competencies & Operational & Entrepreneurial \\
Structure & Formal, mechanistic & Adaptive, loose \\
Controls, reward & Margins, productivity & Milestones, growth \\
Culture & Efficiency, low risk, & $\begin{array}{l}\text { Risk taking, speed, } \\
\text { flexibility, experimentation }\end{array}$ \\
Leadership role & quality, customers & Visionary, involved \\
\hline
\end{tabular}

Source: Adapted from Tushman and O'Reilly, 1996.

\section{Ambidexterity Strategies}

Ambidexterity theories suggest that firms and their managers must overcome these selfenforcing patterns if they are simultaneously to exploit existing business and explore new opportunities in rapidly changing environments (O'Reilly \& Tushman, 2008; Taylor \& Helfat, 2009; Teece, Pisano, \& Shuen, 1997). To remain successful over time, managers and organizations must be able to implement both incremental and revolutionary change (Tushman \& O'Reilly, 1996, p. 8). As shown in Table 1, the ambidexterity framework introduces a number of trade-offs on both operational and strategic levels, making it a 
"key example" of a strategic paradox (Papachroni, Heracleous, \& Paroutis, 2015 Smith, 2014). The ambidextrous firm must simultaneously pursue both an explorative and an exploitative strategy, each of which is internally consistent but which together are contradictory (Smith et al., 2010). This introduces a particular type of leadership challenge, as managers must confront and overcome both personal and organizational needs for consistency (Eisenhardt \& Brown, 1997; O’Reilly \& Tushman, 2013; Smith \& Tushman, 2005). Senior executives, in particular, are regarded as playing an important role in helping organizations to attend to contradictory demands and to foster ambidexterity (see, for example, Birkinshaw \& Gupta, 2013; Gibson \& Birkinshaw, 2004; Lubatkin, Simsek, Ling, \& Veiga, 2006; O’Reilly \& Tushman, 2011; Raisch \& Birkinshaw, 2008; Smith \& Tushman, 2005). Rather than attempting to align and resolve the conflicting demands of exploration and exploitation, executive leaders need to embrace divergence and build the capacity to attend simultaneously to competing and conflicting demands (Smith \& Lewis, 2011), combining the attributes of rigorous cost cutters and of freethinking entrepreneurs (O’Reilly \& Tushman, 2013; Tushman \& O’Reilly, 1996).

In day-to-day business, managers need to achieve operational efficiencies by making incremental improvements to existing products and exploiting existing resources and customers, thereby reducing risk and improving short-term performance. However, to secure a firm's long-term survival, leaders must also plan and prepare for the inevitable revolutions required by discontinuous environmental change (Tushman \& O'Reilly, 1996, p. 11). From the perspective of long-term planning, ambidexterity strategies may be particularly challenging, because even if the theory suggests that a firm must pursue explorative and exploitative activities simultaneously, organizations typically look to leaders to provide definitive answers to questions such as, Should we pursue strategy $A$ or strategy $B$ ? Ambidexterity strategies offer no such resolution, but rather ask, Can we do both? Accordingly, leaders must make seemingly rational and consistent choices in the short term, while remaining acutely aware of accepting strategic paradoxes and contradictions in the long term; doing this "involves consistent inconsistency as managers frequently and dynamically shift decisions" (Smith \& Lewis, 2011, p. 392). Such strategic paradoxes defy rational, linear logic, and may result in frustration for the organization's lower-level workers, who experience management as inconsistent, ambivalent, or even hypocritical (Lewis, 2000; Smith, 2014). This can lead to internal pressure to stick with one strategy, but, as Birkinshaw and Gupta (2013) point out, why would firms need managers, if not to override the organization's natural tendency to resist change and to help it do things that do not come naturally? In summary, fostering and leading organizational cultures that can handle both incremental and discontinuous change is perhaps the most demanding aspect of strategic management (Tushman \& O'Reilly, 1996, p. 24). The arguments above suggest that readiness for change may be needed for the successful implementation of ambidexterity strategies, leading us to propose the following hypothesis.

\section{Hypothesis 1: Readiness for Change is Positively Related to Ambidexterity}

This is in line with previous ambidexterity studies, which suggest that a capacity for change enables firms both to explore and to exploit market opportunities (Papachroni et al., 2015; Taylor \& Helfat, 2009; Tushman \& O’Reilly, 1996). As Judge and Blocker (2008) point out, a sense among the leaders that there is a need to change is undeniably 
the first step in a firm becoming ambidextrous, but simply acknowledging what must be done is not enough; actually following through and implementing changes to pursue both exploitive and exploratory strategies is likely to be the biggest hurdle in a firm's pursuit of strategic ambidexterity (p. 920). This leads to the question of whether it is actually possible to plan for ambidexterity - that is, for both incremental and discontinuous change. There is a long-standing debate regarding whether strategic planning (defined as an organization's process of defining its objectives and making decisions on allocating its resources to pursue this strategy) is beneficial in unstable environments, with one school of thought arguing that strategies come into existence not as "snapshots in time" (for example, though a written and explicit long-term strategic report/statement) but rather through small decisions that are assessed and updated periodically. These small decisions are not predetermined, but emerge logically through experimentation and learning (logical incrementalism).

In this view, strategic planning is of little help for explorative activities (see for example Eisenhardt \& Brown, 1997; Mintzberg 1991, 1994). Another school of thought contends that strategic planning can provide a roadmap to help a firm achieve its vision and goals regardless of environmental stability (see, for example, Ansoff, 1991, 1994). In this view, strategic planning is seen as a deliberate, rational, linear process where first of all the goals are specified, and then a detailed implementation plan is drawn up. Brews and Hunt (1999), in their study of strategy processes at 656 firms, attempted to resolve these conflicting views by suggesting that both the deliberate and the emergent approaches may be part of good strategic planning, especially when firms face increased environmental turbulence. The authors suggest that exploitation strategies in stable environments may require less planning, as firms may rely more on existing routines and capabilities in predictable, slow-moving industries where uncertainty is low. Increased environmental turbulence may force the development of more sophisticated explorative strategies and planning capabilities (Brews \& Hunt, 1999, pp. 905-906). Based on the arguments above, we speculate that the paradoxes inherent in ambidexterity strategies could lead to a greater degree of explicit strategic planning, suggesting a positive relationship between the two.

\section{Hypothesis 2: Strategic Planning is Positively Related to Ambidexterity}

There are two arguments to consider. First, managing strategic paradoxes is presumably more complex than managing a single, internally consistent, strategy. Second, we would expect a stronger relationship between strategic planning and exploration, as exploration represents new strategic territory, while exploiting old certainties may require less strategic planning. This is in line with Kohtamäki, Kautonen, \& Kraus, S. (2010) 's study of ambidexterity strategies: the authors found that strategic planning, defined as "a detailed process that aims to explicate strategy though the analysis of various strategic options" (p. 222), could help facilitate the exploration of new opportunities - in particular, by helping leaders focus on the big picture rather than day-to-day operational details. This study also emphasized the importance of making such strategies understandable and tangible, in order to secure the commitment of lower-level employees to the success of their implementation. Several other studies have also suggested that a compelling strategic plan that justifies the need for simultaneous exploration and exploitation, as well as the relentless and explicit communication of such a strategy, may increase the likeli- 
hood of a firm actually achieving ambidexterity (see for example O'Reilly \& Tushman, 2008, pp. 197-198). Lastly, in line with a number of other studies, we also speculate that ambidexterity strategies are perceived to be linked to improved firm performance (see, for example, Junni, Sarala, Taras, \& Tarba, 2013, and O'Reilly \& Tushman, 2013, for extensive reviews of the literature linking organizational ambidexterity and financial performance). One of the key arguments in the literature is that ambidexterity strategies are needed to secure firm survival in fast-changing, complex business environments, where an either/or approach to strategic planning may be inadequate. To stay competitive, firms and their leaders must adopt a both/and approach, committing to conflicting strategies and their associated product, market, and organizational architectures (Smith et al., 2010, p. 449). Put more succinctly, the reason why leaders pursue strategic paradoxes, given their complexities and inconsistencies, is probably that they believe that this will improve firm performance.

\section{Hypothesis 3: Ambidexterity is Perceived as Positively Related to Firm Performance} In the next section, we outline our research methodologies, procedures, measures, and analysis results. We end the paper with a discussion of the practical implications for both researchers and practitioners, as well as some limitations of our study and avenues for further research.

\section{Methods}

\section{Procedures and Sample}

Our procedures consisted of: (1) one-on-one interviews with top executives in newspaper firms across the Nordic countries; (2) management group sessions in Norway, Sweden, Denmark, and Finland, to explore issues related to strategic planning; and (3) a survey sent to all newspaper executives in the four Nordic countries. In this study, we primarily report on quantitative data from the survey. Our survey sample was based on email lists provided by the relevant publishing organizations in Denmark, Finland, Norway, and Sweden. The survey was distributed to all $(\mathrm{N}=917)$ top media executives (editors and/or business managers) in the four Nordic countries to assess the extent to which they saw their firms as being ready for change, as well as which of a list of 22 pre-defined strategic challenges to the industry they considered to be priorities (Wilberg, $2010 ; 2011 ; 2012$ ). We created this list through management sessions and interviews with news executives, and reviewed, tested, and validated it annually to find the most relevant issues for the industry at the time. The 2012 survey included several new items - exploration, exploitation, and organizational ambidexterity - that were theory-based and were found to be valid and reliable. The survey used Surveymonkey, a popular Webbased survey tool. We first piloted it on a small group of executives and one external researcher. We made some adjustments for clarity and language, and then sent the final survey to respondents in late autumn 2012. At the end of the data collection we had a sample of $\mathrm{N}=143$ executives from the four Nordic countries, representing 13-20\% of the news organizations in each country. The sample sizes and country breakdown for 2012 appear in Table 2. 
Table 2. 2012 Survey Sample Size and Country Breakdown

\begin{tabular}{lcc} 
& $\begin{array}{c}\mathbf{2 0 1 2} \\
\text { Survey responses }\end{array}$ & $\begin{array}{c}\mathbf{2 0 1 2} \\
\text { Survey recipients }\end{array}$ \\
\hline Denmark & 27 & 146 \\
Finland & 28 & 223 \\
Norway & 54 & 376 \\
Sweden & 34 & 172 \\
Total & 143 & 917 \\
\hline
\end{tabular}

\section{Measures}

Organizational ambidexterity (dependent variable). For the purpose of this study, we conceptualized ambidexterity as a multi-dimensional construct comprised of explorative and exploitative capabilities. Thus, in line with existing studies, we computed ambidexterity as an additive integrative construct of multi-item scales for exploration and exploitation (De Visser et al., 2010; Jansen, Tempelaar, Van den Bosch, \& Volberda, 2009; Lubatkin et al., 2006; Revilla, Rodriguez, \& Prieto, 2009). However, we also created both additive $\left(\mathrm{e}^{*} \mathrm{e}\right)$ and subtractive $(\mathrm{e}-\mathrm{e})$ models to be tested.

Exploration and exploitation. In line with previous ambidexterity studies, we constructed separate scale items for exploration and exploitation. We captured exploitation by asking executives to indicate, on a four-point Likert scale, the degree to which they agreed with each of the following statements about their organizations:

1) We offer refined products and services which we know will satisfy our customers (Principal component extraction .77)

2) In our organization, we value experience and professional conduct. This helps us maintain consistently high quality standards (.77)

3) We have a mature product, and know what our readers want and need (.78)

4) We run a pretty tight organization with clearly defined roles and responsibilities (.81)

5) Productivity and efficiency is a core value in our organization (.84)

6) Employees have freedom to improvise on current products (.81)

The items loaded on three factors (refinement, consistency and experience), explaining $79.61 \%$ of the total variance. The Cronbach's alpha for the exploration measure is .60. Hair, Anderson, Tatham, \& Black (2006) note that alpha values above 0.60 are accepted in exploratory studies. Next we created an additive construct comprised of these three factors, which we believe now adequately captures the essence of exploitation: refinement, consistency and experience (March, 1991).

We captured exploration by asking respondents to indicate, on a four-point Likert scale, the degree to which their organization was characterized by each of the following:

1) We have to put out new products to survive (.70)

2) Ongoing redefinition of job descriptions (.81)

3) Constantly changing (.70) 
4) Authority tied to tasks rather than positions (.74)

5) Every failure is seen as a learning experience (.54)

6) We believe in limited structure and flexibility (.61)

The items loaded on three factors (experimentation, flexibility and change), explaining $68.17 \%$ of the total variance. The Cronbach's alpha was .60. Next we created an additive construct comprised of these three factors, which we believe now adequately captures the essence of exploration: experimentation, flexibility and change (March, 1991).

Readiness for change. We captured a firm's perceived readiness for change by asking survey respondents, on a 7-point Likert scale, to assess how ready their firm was for change on the editorial as well as the business side of operations. There was also a comparison with a study from 2006 where the same question in regards to readiness for change had been given to the same target group, with a sample size of $\mathrm{N}=130$.

Firm performance. To measure firm performance, we asked the respondents to rate, on a 5-point Likert scale, how they perceived their firm's performance, in terms of newspaper sales, online users, mobile users, tablet users, print advertising revenues, digital advertising revenues, mobile advertising revenues, and other revenues. We found this scale to have a Cronbach's alpha of .67. We also created separate scales for performance in explorative and exploitative product/market domains respectively. We found it loaded on three components (digital (Web, tablet, mobile)/print/other revenues) for a cumulative eigenvalue of $71.95 \%$. We also asked respondents how much of their total revenues came from the digital side of the business. The market average in the Nordic countries for 2012 was 4\% (PricewaterhouseCoopers Global Media Outlook 2013 - 2017; 2012). We were looking for firms that outperformed the market.

Strategic planning. We asked respondents if they had a written strategic plan for their firm, and also to rank the strategic importance of 22 industry-specific strategy items on a 7-point Likert scale. We wanted to assess the importance of specific strategic intents. This would also allow us to examine the relationship between an organization's capacity/ propensity for ambidexterity (the characteristics of the organization) and the strategic intent. We found this scale to have a Cronbach's alpha of .74.

Control variables. In line with previous ambidexterity studies, we controlled for firm size, country, leaders' functional areas, and perceived environmental munificence (market volatility).

\section{Analysis and Results}

Mean, standard deviation, and correlations among the variables appear in Table 3. Strategic planning and readiness for change is significantly and positively related to ambidexterity. It is interesting to note that strategic planning had a positive relation to exploration, but no significant relation to exploitation. Readiness for change was linked to exploration and exploitation strategies, as well as perceived firm performance. 
Table 3. Correlations, Means and Standard Deviations Between the Measures used in this Study

\begin{tabular}{|c|c|c|c|c|c|c|c|c|c|c|c|c|c|}
\hline & & Mean & St. Dev. & 1 & 2 & 3 & 4 & 5 & 6 & 7 & 8 & 9 & 10 \\
\hline 1 & Exploitation & .000 & 1.732 & & & & & & & & & & \\
\hline 2 & Exploration & .000 & 1.732 & $.260^{* *}$ & & & & & & & & & \\
\hline 3 & Ambidexterity & -.028 & 2.676 & $.786^{* *}$ & $.801^{\star *}$ & & & & & & & & \\
\hline 4 & Strategic Planning & .895 & .307 & .101 & $.198^{*}$ & $.207^{*}$ & & & & & & & \\
\hline 5 & Readiness for change & 5.874 & 1.421 & $.258^{* *}$ & $.257^{* *}$ & $.323^{\text {** }}$ & -.015 & & & & & & \\
\hline 6 & Firm performance & 19.335 & 5.389 & .079 & .123 & .139 & .135 & $.366^{* *}$ & & & & & \\
\hline 7 & Leaders functional area & 1.839 & .801 & -.079 & -.080 & -.096 & -.155 & -.029 & -.108 & & & & \\
\hline 8 & Firm size & 2.671 & .940 & -.001 & $.171^{*}$ & .092 & $.245^{\star \star}$ & .080 & $.281^{\star *}$ & -.005 & & & \\
\hline 9 & Firm country & 2.664 & 1.041 & -.096 & .083 & .030 & -.111 & $-.277^{\star *}$ & -.161 & -.065 & $-.207^{*}$ & & \\
\hline 10 & Type of firm & 1.795 & 1.028 & -.055 & -.008 & -.003 & .119 & .066 & .086 & -.194 * & $.407^{\star *}$ & $-.292^{\star \star}$ & \\
\hline 11 & $\begin{array}{l}\text { Environmental } \\
\text { munificence }\end{array}$ & 30.050 & 5.694 & .009 & $.227^{\star \star}$ & .144 & .105 & .082 & .141 & -.196 * & $.263^{\text {** }}$ & .034 & .066 \\
\hline
\end{tabular}

Note: Number of respondents is 143 rom the four Nordic countries Denmark, Finland, Norway and Sweden. ${ }^{*}$ Correlation is significant at the 0.05 level (2-tailed). ${ }^{* *}$ Correlation is significant at the 0.01 level (2-tailed).

Table 4. Effects of Ambidexterity, Readiness for Change and Strategic Planning, 2012 (Standardized Regression Coefficients)

\begin{tabular}{|c|c|c|c|c|c|c|c|c|c|c|}
\hline & \multicolumn{2}{|c|}{$\begin{array}{c}\text { Model } 1 \\
\text { Dependent variable, } \\
\text { ambidexterity }\end{array}$} & \multicolumn{2}{|c|}{$\begin{array}{c}\text { Model } 2 \\
\text { Dependent variable } \\
\text { ambidexterity }\end{array}$} & \multicolumn{2}{|c|}{$\begin{array}{c}\text { Model } 3 \\
\text { Dependent variable, } \\
\text { ambidexterity }\end{array}$} & \multicolumn{2}{|c|}{$\begin{array}{c}\text { Model } 4 \\
\text { Dependent variable } \\
\text { ambidexterity }\end{array}$} & \multicolumn{2}{|c|}{$\begin{array}{c}\text { Model } 5 \\
\text { Dependent variable, } \\
\text { performance }\end{array}$} \\
\hline & B & SE & B & SE & B & SE & B & SE & B & SE \\
\hline Intercept & 222 & .868 & .135 & 1.592 & -5.495 & 2.003 & -7.899 & 2.142 & 10.740 & 4.680 \\
\hline \multicolumn{11}{|l|}{ Main effects } \\
\hline Ambidexterity & & & & & & & & & -.061 & .194 \\
\hline Readiness for change & & & & & $.375^{\star \star \star}$ & .173 & $.394^{\star \star \star}$ & .169 & $.358^{\star \star \star}$ & .378 \\
\hline Strategic planning & & & & & & & $.236^{\star \star}$ & .775 & .143 & 1653 \\
\hline \multicolumn{11}{|l|}{ Control variables: } \\
\hline Leaders functional area & -.092 & .319 & -.088 & .328 & -.084 & .307 & -.030 & .306 & -.041 & .641 \\
\hline Firm size & .136 & .201 & .150 & .204 & .165 & .191 & .127 & .188 & .142 & .392 \\
\hline Firm type & -.072 & .278 & -.059 & .293 & -.025 & .275 & -.018 & .268 & -.042 & .554 \\
\hline Firm country & & & .063 & .267 & .179 & .261 & .202 & .255 & -.070 & .539 \\
\hline Environmental munificence & & & -.066 & .356 & -.039 & .334 & -.046 & .325 & -.079 & .678 \\
\hline$F$ improvement of fit change & .878 & & .452 & & $17.681^{* \star \star}$ & & $7.374^{\star *}$ & & & \\
\hline R Squared & .022 & & .029 & & $.158^{\star \star \star}$ & & $.208^{\star \star}$ & & .185 & \\
\hline Adjusted R Squared & -.003 & & -.012 & & .114 & & .160 & & .126 & \\
\hline ANANOVA F & .878 & & .702 & & $3.615^{\star \star}$ & & $4.323^{\star \star *}$ & & $3.099^{* *}$ & \\
\hline
\end{tabular}

Note: Number of respondents is 143 from the four Nordic countries Denmark, Finland, Norway and Sweden. Standardized regression coefficients are shown in the table. ${ }^{*} p<.05 .{ }^{* \star} p<.01 .{ }^{* \star *} p<.001$.

\section{Main Effects}

Next, we tested the main effects by employing a multiple regression analysis, entering independent variables cumulatively to assess the increments in variance explained. The results of the analyses appear in Table 4. For the hypotheses regarding ambidexterity, the firm control variables first appear in Model 1, but show no significant effect on the variance in ambidexterity. In Model 2, we added the environmental control variables, with no significant effect. In Model 3 we add the first main effect, finding that readiness for change significantly improves the fit of the model, now accounting for $15.8 \%$ of the variance in ambidexterity $(\mathrm{p}<.001)$. 
Table 5. Strategic Planning - Importance of Key Strategic Issues over the Next Three Years (Correlations)

\begin{tabular}{llll} 
& $\begin{array}{c}\text { Explorative } \\
\text { Firm }\end{array}$ & $\begin{array}{c}\text { Explorative } \\
\text { Firm }\end{array}$ & $\begin{array}{c}\text { Ambidextrous } \\
\text { Firm }\end{array}$ \\
\hline Focus on profitability in all parts of the organization & -.043 & .125 & $.183^{*}$ \\
Focus on collaboration with other firms & $.240^{* *}$ & $-.320^{* *}$ & .137 \\
Rapid implementation of changes & .127 & -.092 & .035 \\
Reduction in number of employees & .104 & -.130 & .024 \\
Product development - editorial & .150 & -.048 & .049 \\
Product development - market and advertising & .147 & .036 & $.189^{*}$ \\
Stable and reliable distribution & .091 & -.004 & .000 \\
Better market research/documentation & $.165^{*}$ & .092 & -.012 \\
Spend more money on Web site(s) & .100 & -.129 & .138 \\
Increase marketing budgets & .147 & -.090 & .006 \\
Top customer service & -.066 & .065 & $.169^{*}$ \\
Development of the firm brand & $.305^{* *}$ & $-.219^{* *}$ & .010 \\
Develop employee competences & $.225^{* *}$ & -.130 & .096 \\
Develop a good working environment & .045 & .041 & .070 \\
Encourage cooperation between departments & $.172^{*}$ & -.089 & .113 \\
Increase overall competence in the organization & $.276^{* *}$ & -.130 & -.016 \\
Relationships/alliances with competitors & $.284^{* *}$ & $-.173^{*}$ & .126 \\
Management and leader development & $.275^{* *}$ & -.083 & -.120 \\
Board level competence & .139 & $-.188^{*}$ & $.180^{*}$ \\
More interaction with users & .101 & $-.185^{*}$ & .018 \\
Application of new technology/software & $.175^{*}$ & -.061 & $.239^{* *}$ \\
Experiment with new business models & .143 & $-.192^{*}$ & .126 \\
\hline
\end{tabular}

Note: Number of respondents is 81 from the four Nordic countries Denmark, Finland, Norway and Sweden. We deployed the median cut off (He \&Wong, 2004). ${ }^{* *}$ Correlation is significant at the 0.01 level (2-tailed). ${ }^{*}$ Correlation is significant at the 0.05 level (2-tailed).

This supports Hypothesis 1, which proposes a link between readiness for change and ambidexterity. Adding strategic planning in Model 4 further improves the fit of the model, which now accounts for $21 \%$ of the variance in ambidexterity $(\mathrm{p}<.01)$. This supports Hypothesis 2, which suggests a positive link between ambidexterity and strategic planning. In Model 5 we test for the link between ambidexterity and firm performance, while controlling for the other variables. We find no significant relation. This means we must reject Hypothesis 3, which suggests a positive link between ambidexterity and firm performance. We will discuss this somewhat surprising finding in the discussion section.

Table 5 summarizes the significant correlations on the 22 industry-specific strategic items. In line with He and Wong (2004), and Cao, Gedajlovic, \& Zhang (2009), we focused on firms with 50 employees or more, and divided our sample into three firm groups based on a median cut-off criterion, ranking them in descending order of explorative or exploitative factor scores. We coded firms that fell in the upper half of the explorative ranking as such, and did the same for those falling in the upper half of the exploitative rankings. A firm was ambidextrous if it belonged in both upper halves. In this post-hoc analysis, we found that $26 \%$ of the firms could be classified as ambidextrous, based on 
leader responses. For these, the top strategic priorities included the application of new technologies, market-driven product development, and top customer service. "Explorative" firms gave significantly stronger importance to strategic intents in regards to collaborations with other firms, or even competitors, developing both brand and internal competences on all levels of the organization. "Exploitative" firms saw significant negative consequences in relation to experimenting with new business models, technologies, and alliances with competitors. This should prove quite challenging in the long term, given the rapid changes in the news industry.

\section{Discussion}

In this study, we found a link between ambidexterity and a readiness for change. Without a recognition that change is needed, leaders would probably just go about their daily business, failing to explore new, potentially disruptive, technologies and business opportunities. However, given that the newspaper industry has been in constant turmoil and change over the past decade, a recognized need for change is not enough. Leaders should not just talk about change: they need to plan and execute strategic paradoxes. Based on our review of the literature, we predicted a link between strategic planning and ambidexterity. Our data confirmed this. We had some concerns as to the validity of this finding, however. It could simply be the case that larger firms do more strategic planning (because of their size) and are more likely to be ambidextrous because of resource slack - they have the resources both to explore digital opportunities and to exploit their legacy print business. In our regression models on ambidexterity, we controlled for firm size, finding no significant effect. Second, we had a concern about reversed causality. Is ambidexterity an antecedent to strategic planning? We suggest that it is an iterative process, a dynamic interaction. Explicit and detailed strategic planning may help a firm to navigate the complexities of explorative digital domains, but such plans need continuous revision as the frontline of technological innovation shifts. In theory, exploiting the "old certainties" of the legacy print business may require less strategic planning if the legacy business could simply be left to its own devices. However, the inherent dilemma in ambidexterity strategies is that every strategic move made in explorative digital domains may disrupt the exploitation of print domains. This means that any ambidexterity strategy must consider both dimensions and be continuously updated and realigned to reflect changing market dynamics.

Our study suggests a significant positive relationship between strategic planning and exploration, but no significant relationship between strategic planning and exploitation. This fits with our observation that newspaper firms are quite elaborate in their digital strategizing, but less clear about the implications for exploitation strategies. It seems as if the tendency is to attempt to align digital exploration and print exploitation into some sort of consistent middle-of-the-road strategic framework, without accounting for the inherent dilemmas and paradoxes involved in radical exploration and exploitation. We have rarely seen newspaper strategies that recognize and embrace paradoxical and conflicting objectives. This is of course quite rational behaviour, as most managers arguably get paid to fix problems - not to invite conflicts with inconsistent strategic objectives. 
Figure 1. Strategic outlook: Development of Nordic newspaper industry revenues 20082017 (USD in billions)

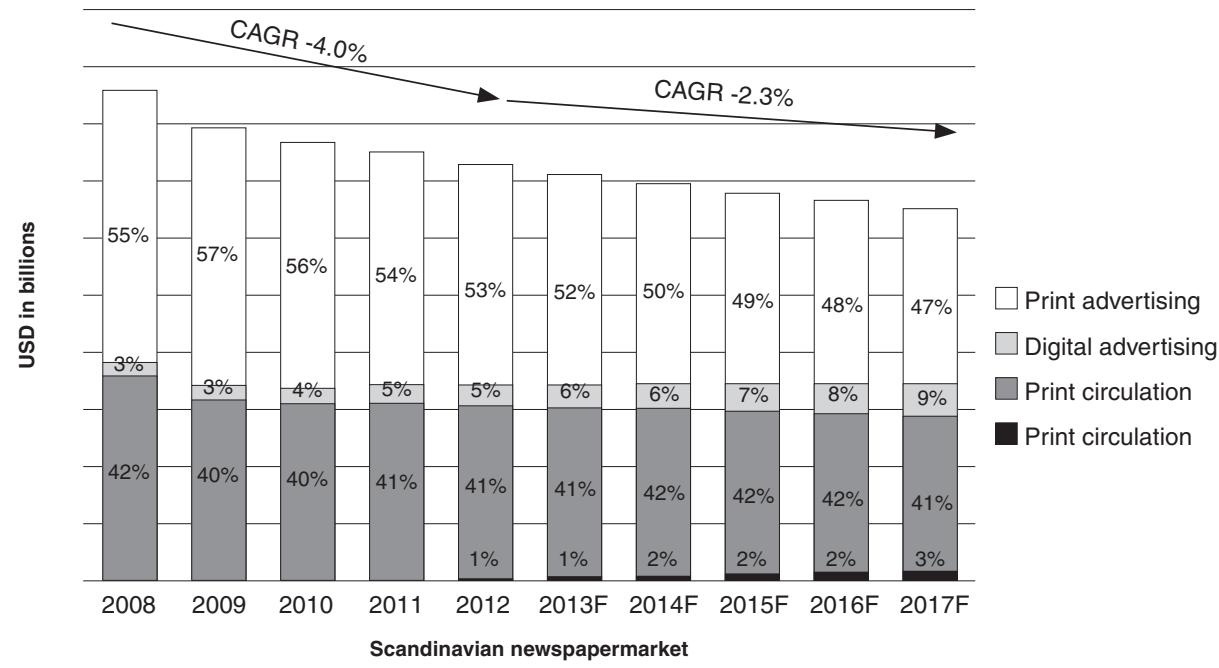

Source: PricewaterhouseCoopers Global Media Outlook 2013 - 2017 (2012).

Indeed, strategic paradoxes may be of more interest to academics than to practising managers. After all, a paradox is by definition a proposition that works well in theory, but may seem senseless, logically unacceptable, or self-contradictory in practice. As Birkinshaw and Gupta (2013) note, the paradoxical nature of ambidexterity may be part of its attraction to researchers, but ambidexterity is an academic construct, which may offer little intuitive meaning to practising managers - unlike other management literature terms such as innovation, growth, or leadership (p. 290).

However, we would argue that any simplistic, one-sided strategy could have dire real-life financial consequences. Our study suggests that the discomforts of these strategic paradoxes should be seen as growing pains, as firms and leaders learn to do new things. Facing the complex business realities of the digital era, top leaders have to tackle inconsistencies and even to risk appearing hypocritical as they balance short-term and long-term goals. We have seen many executive keynotes showcasing the next big digital opportunity that were followed a few months later by much less-publicized quarterly financial results, with red numbers foreshadowing another round of cost reductions and budget constraints in print operations. This brings us to the link between ambidexterity strategies and firm performance.

Our study did not find that leaders perceived ambidexterity strategies to be linked to improved firm performance. This is in contrast with the ambidexterity premise (Raisch, Birkinshaw, Probst, \& Tushman, 2009), but fits a pattern we have seen over the past decade in the given empirical context - for most newspaper companies, growth in explorative digital product/market domains has come at the cost of persistent revenue declines in the legacy print business, leading to a general decline in industry profitability. As indicated by Figure 1, the outlook for the period from 2012-2017 is further decline. A similar pattern emerges though a more granular analysis of the previous research into the link between ambidexterity and performance. See, for example, Junni et al. (2013), who in their meta-analysis of empirical studies to date found that exploitation strategies 
are linked to profits, whereas exploration strategies are linked to growth, which implies that ambidexterity may have quite different impacts on different aspects of firm performance (p. 308). The empirical context of our study supports this argument, and suggests a direct conflict between digital exploration and print exploitation. However, newspaper leaders have no choice but to continue digital exploration even if it slowly eradicates their legacy print business and overall industry revenues keep dropping. This is just one of the inherent paradoxes in ambidexterity strategies.

\section{Conclusion}

The purpose of this study has been to examine how executive leaders manage the paradoxes introduced by ambidexterity strategies. This can be one of the toughest leadership challenges, as it requires managers to embrace consistencies and contradictions. Ambidextrous leaders may make rational and consistent choices in the short term, while remaining acutely aware of accepting contradictions in the long term. Such inconsistency is probably an acquired taste for most. In closing, we would like to offer a telling example of an emerging strategic paradox in the context of the newspaper industry. Consider the recent trend of online paywalls - newspaper firms requiring online readers to pay to access news and other content on their Web sites. In our view, these paywall strategies, heralded as an innovative industry move, really indicate the organizational need for consistency. A paywall strategy attempts to eliminate the challenges of managing two different and directly conflicting business models simultaneously - namely having a paid-for print newspaper while also offering news for free online (Markides, 2013). This one consistent pay-for-news strategy across print and digital domains may look good on paper for top executives. However, it is very likely to introduce a new strategic paradox. How can newspaper firms hope to compete for new digital revenues against open access, free-for-all social media such as Facebook, Twitter, or Google if top management decides to erect digital paywalls that keep potential new audiences out?

\section{Limitations}

This study involves cross-sectional data from single informants using perceptual scales, which potentially introduces common bias effect - some of the observed co-variation between variables may be due to a shared method of measurement. To control for such bias, we deployed five specific procedural remedies ex ante as suggested by Podsakoff, MacKenzie and Podsakoff (2012) to maximize respondent motivation and ability to respond accurately. First, we deployed a proximal separation between the constructs for exploration and exploitation, by means of dedicated buffer items, to diminish the use of prior responses to answer subsequent questions (Podsakoff, MacKenzie, Lee, \& Podsakoff, 2003). Second, we minimized the scale properties shared between the predictor and criterion variables by using varying Likert scales/items so the respondents would not combine related items. Third, based on our pilot survey, we improved the scale items to remove ambiguity, keeping questions simple, specific, clear and concise. In line with suggestions from Krosnick (1991), we also labelled every point on the response scale to reduce ambiguity further. Fourth, we introduced positive and negative items to control 
for response style tendencies that may produce misleading factor scores and deflate or inflate regression scores. As suggested by Chang, van Wittleloostuijn and Eden (2010), we assured respondents of the study's anonymity and confidentiality, that there were no right or wrong answers, and that we valued their honesty. We believe these remedies should minimize common method bias, but we also performed Harman's one-factor test on items included in the regression models. If common method bias were still a problem in the study, we would expect either a single factor to emerge from factor analysis, or one general factor to account for the majority of the covariance among the variables (Mom, van den Bosch, \& Volderda, 2009; Podsakoff \& Organ, 1986; Podsakoff, Todor, Grover, \& Huber, 1984; Podsakoff et al., 2003). We did not find such a single factor. Note that the methods deployed in this study are designed to establish relationships between constructs, not causality.

\section{References}

Ansoff, H. Igor (1991). Critique of Henry Mintzberg's ‘The Design School: Reconsidering the Basic Premises of Strategic Management'. Strategic Management Journal, 12, 449-461.

Ansoff, H. Igor (1994). Comment on Henry Mintzberg's 'Rethinking Strategic Planning'. Long Range Planning, 27(3), 31-32.

Benner, Mary J., \& Tushman, Michael L. (2003). Exploitation, exploration, and process management: The productivity dilemma revisited. Academy of Management Review, 28(2), 238-256.

Birkinshaw, Julian, \& Gupta, Kamini (2013). Clarifying the distinctive contribution of ambidexterity to the field of organization studies. Academy of Management Perspectives, 27, 287-298.

Brews, Peter J., \& Hunt, Michelle R. (1999). Learning to plan and planning to learn: Resolving the planning school/learning school debate. Strategic Management Journal, 20(10), 889-913.

Brown, Shona L., \& Eisenhardt, Kathleen M. (1997). The art of continuous change: Linking complexity theory and time-paced evolution in relentlessly shifting organizations. Administrative Science Quarterly, 42, 1-34.

Cao, Qing, Gedajlovic, Eric, \& Zhang, Hongping (2009). Unpacking organizational ambidexterity: Dimensions, contingencies and synergistic effects. Organization Science, 20: 781-796.

Chang, Sea-Jin, van Wittleloostuijn, Arjen, \& Eden, Lorraine (2010). From the editors: Common method variance in international business research. Journal of International Business Studies, 41, 178-184.

Christensen, Clayton M. (1997). The innovator's dilemma: When new technologies cause great firms to fail. Boston, MA: Harvard Business School Press.

De Visser, Matthias, de Weerd-Nederhof, Petra, Faems, Dries L., Song, Michael, van Looy, Bart, \& Visscher, Klaasjan (2010). Structural ambidexterity in NPD processes: A firm-level assessment of the impact of differentiated structures on innovation performance. Technovation 30, 291-299.

Gibson, Christina B., \& Birkinshaw, Julian (2004). The antecedents, consequences, and mediating role of organizational ambidexterity. Academy of Management Journal, 47, 209-226.

He, Zi-Lin, \& Wong, Poh Kam (2004). Exploration vs. exploitation: An empirical test of the ambidexterity hypothesis. Organizational Science, 15, 481-494.

Hair, Joseph F., Anderson, Rolph E., Tatham, Ronald L., \& Black, William C. (1995). Multivariate data analysis with readings. Englewood Cliffs, NJ: Prentice Hall.

Jansen, Justin J., Vera, Dusya, \& Crossan, Mary (2009). Strategic leadership for exploration and exploitation: The moderating role of environmental dynamism. The Leadership Quarterly, 20, 5-18.

Jansen, Justin J., Tempelaar, Michiel P., van den Bosch, Frans A., \& Volberda, Henk W. (2009). Structural differentiation and ambidexterity: The mediating role of integration mechanisms. Organization Science, 20, 797-811.

Judge, William Q., \& Blocker, Christopher P. (2008). Organizational capacity for change and strategic ambidexterity. Flying the plane while rewiring it. European Journal of Marketing, 42(9/10), 915-926.

Junni, Paulina, Sarala, Riika M., Taras, Vas, \& Tarba, Shlomo Y. (2013) Organizational ambidexterity and performance: A meta-analysis. Academy of Management Perspectives, 27(4), 299-312.

Kohtamäki, Marko, Kautonen, Teemu, \& Kraus, Sascha (2010). Strategic planning and small business performance. International Journal of Entrepreneurship and Innovation, 11(3), 221-229.

Krosnick, Jon A. (1991). Response strategies for coping with the cognitive demands of attitude measures in surveys. Applied Cognitive Psychology, 5, 213-236. 
Levinthal, Daniel, \& March, James G. (1993). The myopia of learning. Strategic Management Journal, 14 (Special Issue), 95-112.

Lewis, Marianne W. (2000). Exploring paradox: Toward a more comprehensive guide. Academy of Management Review, 25(4), 760-776.

Lubatkin, Michael H., Simsek, Zeki, Ling, Yan, Veiga, John F. (2006). Ambidexterity and performance in small- to medium-sized firms: The pivotal role of top management team behavioral integration. Journal of Management, 32, 646-672.

March, James G. (1991). Exploration and exploitation in organizational learning. Organization Science 2, 71-87.

Markides, Constantinos C. (2013). Business model innovation: What can the ambidexterity literature teach us? Academy of Management Perspectives, 27(4), 311-323.

Mintzberg, Henry (1991) Learning 1, Planning 0: Reply to Igor Ansoff. Strategic Management Journal 12, 463-466.

Mintzberg, Henry (1994). Rethinking strategic planning, Part I: Pitfalls and fallacies. Long Range Planning, 27(3). 12-21.

Mom, Tom J. M., van den Bosch, Frans A. J., \& Volderda, Henk W. (2009). Understanding variation in managers' ambidexterity: Investigating direct and interaction effects of formal structural and personal coordination mechanisms. Organization Science, 20(4), 812-828.

O'Reilly, Charles A., \& Tushman, Michael L. (2008). Ambidexterity as a dynamic capability: Resolving the innovator's dilemma. Research in Organizational Behavior, 28, 185-206.

O’Reilly, Charles A., \& Tushman, Michael L. (2011). Organizational ambidexterity in action: How managers explore and exploit. California Management Review, 53, 1-18.

O’Reilly, Charles A., \& Tushman, Michael L. (2013). Organizational ambidexterity: Past, present, and future. Academy of Management Perspectives, 27(4), 324-338

Papachroni, Angeliki, Heracleous, Loizos, \& Paroutis, Sotirios (2015). Organizational ambidexterity through the lens of paradox theory: Building a novel research agenda. The Journal of Applied Behavioral Science, 1-23.

Podsakoff, Philip M., \& Organ, Dennis W. (1986). Self-reports in organizational research: Problems and prospects. Journal of Management, 12(4), 531-544.

Podsakoff, Philip M., MacKenzie, Scott B., Lee, Jeong-Jeon, \& Podsakoff, Nathan P. (2003). Common method variance in behavioral research: A critical review of the literature and recommended remedies. Journal of Applied Psychology, 88, 879-903.

Podsakoff, P.M., MacKenzie, S.B., \& Podsakoff, N.P. (2012). Sources of method bias in social science research and recommendations on how to control it. Annual Review of Psychology, 65, 539-569.

Podsakoff, Philip M., Todor, William D., Grover, Richard A., \& Huber, Vandra L. (1984). Situational moderators of leader reward and punishment behaviors: Fact or fiction? Organizational Behavior and Human Performance, 34(1), 1-63.

PricewaterhouseCoopers Global Media Outlook 2013-2017 (2012). Accessed online at: https://www.pwc.no/ no/innsikt/entertainment-media/global-media-outlook-2013.pdf

Raisch, Sebastian, \& Birkinshaw, Julian (2008). Organizational ambidexterity: Antecedents, outcomes, and moderators. Journal of Management, 34, 375-409.

Raisch, Sebastian, Birkinshaw, Julian, Probst, Gilbert, \& Tushman, Michael L. (2009). Organizational ambidexterity: Balancing exploitation and exploration for sustained performance. Organization Science, 20, 685-695.

Revilla, Elena, Rodríguez-Prado, Beatriz, \& Prieto, Isabel (2009). Information technology as a knowledge management enabler in product development: Empirical evidence. European Journal of Innovation Management, 12(3), 346-363.

Smith, Wendy K. (2014). Dynamic decision making: A model of senior leader managing strategic paradoxes. Academy of Management Journal, 57(6), 1592-1623.

Smith, Wendy K., \& Lewis, Marianne W. (2011). Toward a theory of paradox: A dynamic equilibrium model of organizing. Academy of Management Review, 36, 381-403.

Smith, Wendy K., \& Tushman, Michael L. (2005). Managing strategic contradictions: A top management model for managing innovation streams. Organization Science, 16, 522-536.

Smith, Wendy K., Binns, Andy, \& Tushman, Michael (2010). Complex business models: Managing strategic paradoxes simultaneously. Long Range Planning, 43, 448-461.

Taylor, Alva, \& Helfat, Constance E. (2009). Organizational linkages for surviving technological change: Complementary assets, middle management, and ambidexterity. Organizational Science, 20(4), 718-739.

Teece David J., Pisano Gary, \& Shuen, Amy (1997). Dynamic Capabilities and Strategic Management. Strategic Management Journal, 18(7), 509-533. 
Tushman, Michael, \& Romanelli, Elaine (1985). Organizational evolution: A metamorphosis model of convergence and reorientation. In L. L. Cummings and B. M. Staw (Eds.), Research in Organizational Behavior, Vol. 7, (pp. 171-222), Greenwich, CT: JAI Press.

Tushman, Michael L., \& O'Reilly, Charles A. (1996). The ambidextrous organization: Managing evolutionary and revolutionary change. California Management Review, 38(4): 8-30.

Wilberg, Erik (2010). Mediaprospect 2011 - Analyses for the coming year. Oslo: BI Norwegian Business School, Oslo.

Wilberg, Erik (2011). Mediaprospect 2012 - Analyses for the coming year. Oslo: BI Norwegian Business School, Oslo.

Wilberg, Erik (2012). Mediaprospect 2013 - Analyses for the coming year. Oslo: BI Norwegian Business School, Oslo.

TOR-BØE LILLEGRAVEN, Ph.D., Department of Strategic Management and Globalization, Copenhagen Business School, tor.lillegraven@gmail.com

ERIK WILBERG, Dr., Associate Professor, Department of Strategy and Logistics, BI Norwegian Business School, erik.wilberg@bi.no 